\title{
Sexually mediated shedding of Myxobolus fallax spores during spermiation of Litoria fallax (Anura)
}

\author{
Robert K. Browne ${ }^{1, *}$, Hong $\mathrm{Li}^{2}$, Michael Vaughan ${ }^{3}$ \\ ${ }^{1}$ Department of Biological Sciences, University of Newcastle, University Drive, Callaghan, New South Wales 2308, Australia \\ ${ }^{2}$ Shanghai Zoo, Shanghai 200335, PR China \\ ${ }^{3}$ Rhodes College, 1873 North Parkway, Memphis, Tennessee 38107, USA
}

\begin{abstract}
Myxobolus fallax (Myxosporea) infects the testes of the dwarf green tree frog Litoria fallax without apparently affecting the host's health, behavior, or testicular sperm numbers or quality. We investigated the shedding $M$. fallax spores and the relationship between $M$. fallax infection and fertility in L. fallax. During natural spawning, comparisons were made between the prevalence and intensity of M. fallax infection, spore shedding, and fertilization rates. During the hormonal induction of spermiation, comparisons were made between the prevalence and intensity of $M$. fallax infection, and the number of sperm and spores shed. During natural spawning, the prevalence or intensity of infection or spore shedding did not affect fertility. Spermiation and spore shedding was induced in 10 males by the administration of human chorionic gonadotrophin, with 10 controls. Histology showed that all 10 males were infected by M. fallax. The controls shed no sperm or spores. Nine infected males shed sperm $3 \mathrm{~h}$ post-administration (PA), and 3 of these also shed spores. Only the 3 males that shed sperm and spores at $3 \mathrm{~h}$ PA also shed sperm at $6 \mathrm{~h} \mathrm{PA}$, at which time they also shed spores. In total, the 3 males that shed spores gave higher sperm numbers than the 6 males that did not shed spores. Overall, these results show that the shedding of $M$. fallax spores is sexually mediated through reproductive hormones without affecting fertility.
\end{abstract}

KEY WORDS: Parasite - Myxobolus fallax - Litoria fallax - Reproduction · Hormone $\cdot$ Sperm · Spores $\cdot$ Transmission

Resale or republication not permitted without written consent of the publisher

\section{INTRODUCTION}

Myxobolus spp. (Myxosporea; Butschli 1882) infect both anurans and fish (Lansberg \& Lom 1991, Browne et al. 2003). In fish, Myxobolus spp. infect a diverse set of tissues including the integument, eyes, gills, skeleton, muscle, digestive tract, nervous system, kidneys, and gonads (Landsberg \& Lom 1991, Ali et al. 2002, Bahri et al. 2003). In anurans, Myxobolus spp. infections are mostly found in cysts in the testes or organs associated with the urogenital tract (Browne et al. 2003). During studies on the cryopreservation of anuran sperm, Myxobolus sp. spores were observed in the macerated testes of the dwarf green tree frog Litoria fallax. A new species, M. fallax, was distinguished by the morphometrics of these spores. (Browne et al. 2003). In contrast to the pathologies caused by Myxobolus spp. in fish (Cone 1998, Kent 2000, Ali et al. 2002) and in other anurans (Johnston \& Bancroft 1918, Ewers 1973), M. fallax benignly infects the testes of $L$. fallax without affecting the health or behavior of the host, or their testicular sperm numbers or quality (Browne et al. 2003). In L. fallax, M. fallax cysts were not observed in other organs associated with the urogenital tract: the vasa efferentia, kidney, or urinary bladder (Browne et al. 2003).

Prior to their release during spawning, the sperm of anurans are stored in the testis. The release of sperm from the testis (spermiation) is induced by a luteinizing hormone that affects the seminiferous tubules (Burgos \& Vitale-Calpe 2005). The seminiferous tubules contain spermatogenic cysts, which are surrounded by Sertoli cells (Sprando \& Russel 1998). Swelling of the Sertoli cells releases sperm from the spermatogenic 
cysts, and continued swelling unfolds the recesses of the Sertoli cell layer and flushes sperm into the lumen of the tubules. From the testes, the sperm pass through the vasa efferentia, into the kidney, through the Wolffian duct, and then may be stored in the urinary bladder before release through the cloaca (Pudney 1995, Sprando \& Russel 1998). Therefore, the mechanism for the shedding of Litoria fallax sperm from spermatogenic cysts is through hydraulic pressure from increased hydration, which is mediated by reproductive hormones. The release of Myxobolus fallax spores from cysts within the testes could be subject to the same endocrine controls. To enter the aquatic stage, M. fallax spores would follow the same path as sperm.

Besides the expression of sperm during natural spawning, spermiation can be induced through the administration of artificial hormones such as human chorionic gonadotrophin (hCG) (Browne et al. 2006). We investigated the mechanism of the shedding of Myxobolus fallax spores and the relationship between $M$. fallax infection and fertility. During natural spawning, comparisons were made between the prevalence and intensity of $M$. fallax infection, spore shedding, and fertilization rates, and during the hormonal induction of spermiation, comparisons were made between the numbers of shed sperm and spores, and the prevalence and intensity of $M$. fallax infection. Previous studies did not include histological examinations of the kidneys, where-unlike in the thin translucent membranes of the vasa efferentia, Wolffian duct, and urinary bladder - small cysts might reside undetected (Browne et al. 2003). In this study, we included histological studies of the kidneys to determine the presence of $M$. fallax spores or cysts.

\section{MATERIALS AND METHODS}

Expt 1. Natural spermiation, prevalence and intensity of Myxobolus fallax infection, spore shedding, and fertility. Six amplexing pairs of Litoria fallax were collected from a pond (K1: $32^{\circ} 51^{\prime} \mathrm{S}, 151^{\circ} 42^{\prime} \mathrm{E}$ ) on Kooragang Island (KI), Newcastle, New South Wales, Australia, during December 1999. In November 1999, L. fallax from this pond had shown a prevalence of infection by $M$. fallax of $69 \%$ (Browne et al. 2003). Each frog was weighed to $0.01 \mathrm{~g}$ and the snout-vent length measured to $0.1 \mathrm{~mm}$. Each pair of frogs was placed for $12 \mathrm{~h}$ at $23^{\circ} \mathrm{C}$ in a plastic food container ( $20.0 \mathrm{~cm}$ length $\times 12.5 \mathrm{~cm}$ width $\times 10.0 \mathrm{~cm}$ height) containing $1.3 \% \mathrm{v} / \mathrm{v}$ of Simplified Amphibian Ringer (SAR: $113.0 \mathrm{mM} \mathrm{NaCl}, 1.0 \mathrm{mM} \mathrm{CaCl}_{2}, 2.0 \mathrm{mM} \mathrm{KCl}$, $3.6 \mathrm{mM} \mathrm{NaHCO}_{3} ; 220 \mathrm{mOsm} \mathrm{kg}^{-1}$; Browne et al. 2002) to distilled water. Five of the 6 pairs spawned and the eggs of each spawning pair were kept separately until hatch. At hatch, the number of infertile eggs and hatching larvae (stage 26 to 28 Daudin; Nieuwkoop \& Faber 1996) were counted for each pair. After the $12 \mathrm{~h}$ period, an aliquot of water was sampled from each container and examined for M. fallax spores. Sperm could not be accurately counted as they lyse after more than $3 \mathrm{~h}$ in water. The presence of $M$. fallax spores was observed under phase-contrast light microscopy at $400 \times$ magnification. $M$. fallax spores are approximately oval, and measure $13.4 \pm 0.5 \mu \mathrm{m}$ in length, $9.5 \pm 0.4 \mu \mathrm{m}$ in width, and $6.8 \pm 0.4 \mu \mathrm{m}$ in depth. Male frogs were euthanased by injection of $0.4 \%(\mathrm{w} / \mathrm{v})$ aqueous tricaine methane-sulfonate (MS222) (Ruth Consolidated Industries) into the dorsal lymph sac (Browne et al. 2002). The testes and kidneys were then excised, weighed to $0.0001 \mathrm{~g}$, fixed with Histochoice Tissue Fixative (Astral Scientific), dehydrated with alcohol, then embedded in paraffin. Three $6.0 \mu \mathrm{m}$ sections were then taken from each testes and kidney, stained with haemotoxylin and eosin, and examined under phasecontrast light microscopy at $400 \times$ magnification for the presence and maturity of $M$. fallax cysts. Testes with large mature cysts occupying a substantial volume of the testes were considered to have a high intensity of infection (High), and those with immature and mature cysts in patches within unaffected tissue were considered to have a low intensity of infection (Low). Mature cysts are approximately 300 to $400 \mu \mathrm{m}$ in diameter, and loosely packed with spores. In contrast, plasmodia with developing cysts are dense. There may be both mature cysts and plasmodia in the same testes. This intensity of infection was reflected in the combined mass of the testes where uninfected testes weigh approximately $0.0060 \mathrm{~g}$, testes with a low intensity of infection weigh up to $0.0080 \mathrm{~g}$, and those with a high intensity of infection weigh more than $0.0080 \mathrm{~g}$ (Tables $1 \& 2$ ).

Expt 2. Induction of spermiation of Litoria fallax, prevalence and intensity of Myxobolus fallax infection, and spore shedding. Twenty calling $L$. fallax males were collected from a KI pond (K3: $32^{\circ} 52^{\prime} \mathrm{S}$, $151^{\circ} 43^{\prime}$ E) during December 1999. In November 1999, L. fallax from this pond showed $100 \%$ percent prevalence of infection by M. fallax (Browne et al. 2003). These males were separated into 2 groups of 10: 1 treatment and 1 control. Males were treated by injection of 20 international units (IU) of hCG (Chorulon) dissolved in $0.25 \mathrm{ml}$ of SAR into the dorsal lymph sac. The controls were only injected with $0.25 \mathrm{ml}$ of SAR. The frogs were then placed individually in Petri dishes containing $2.0 \mathrm{ml}$ of distilled water with $0.03 \mathrm{ml}$ of SAR and kept at $23^{\circ} \mathrm{C}$. At $3 \mathrm{~h}$ post-administration (PA), a $0.02 \mathrm{ml}$ aliquot of water was sampled and spores and sperm counted. The concentration of $M$. fallax spores and L. fallax sperm was measured with a haemocytometer by phase-contrast light microscopy at $400 \times$ 
magnification. For some counts with low spore numbers, several aliquots were counted. The total number of spores was calculated from the concentration of spores and total volume of spawning water. The frogs were then placed in a fresh $2.0 \mathrm{ml}$ sample of water with $\mathrm{SAR}$, and at $6 \mathrm{~h}$ PA a $0.02 \mathrm{ml}$ aliquot was sampled and spores and sperm counted. The frogs were then euthanased, and the testes and kidneys excised, weighed, fixed, and examined histologically for the intensity of $M$. fallax infection.

Statistical analysis. The weight of the left and right testes was summed. Sperm and spore numbers and testes weights from Expt 2 were compared by $t$-tests. All statistical analyses were performed using the JMP 5.1 software package (SAS Institute). Data are expressed as mean $\pm \mathrm{SE}$.

\section{RESULTS}

\section{Expt 1. Natural spermiation, prevalence and intensity of Myxobolus fallax infection, spore shedding, and fertility}

Five of the 6 pairs of Litoria fallax spawned and Myxobolus fallax spores were shed by 1 pair. The testes of males of all 5 spawning pairs were infected with $M$. fallax. Eggs from the pair where the male shed spores had a $98 \%$ hatching rate, and a high intensity of $M$. fallax infection was evident in their testes, which in total weighed $0.025 \mathrm{~g}$ (approximately 6 times the weight of uninfected testes) (Browne et al. 2003). The intensity of M. fallax infection had no apparent effect on hatching success, with sperm from the 2 most infected males producing 94 and $98 \%$ hatch rates (Table 1). There were no $M$. fallax cysts or spores detected in the kidneys.

\section{Expt 2. Induction of spermiation of Litoria fallax, prevalence and intensity of Myxobolus fallax infection, and spore shedding}

Control frogs shed no sperm or spores. Nine of the treatment group shed sperm $3 \mathrm{~h}$ after treatment, with an average number of $2.0 \pm 1.0 \times 10^{6} ; 3$ of these 9 frogs also shed spores at an average number of $1.9 \pm 1.3 \times$ $10^{6}$. The frogs that shed spores produced higher average sperm numbers $\left(4.0 \pm 2.9 \times 10^{6}\right)$ than those that did not shed spores $\left(1.0 \pm 0.6 \times 10^{6}\right)$. Sperm were also shed $6 \mathrm{~h}$ PA in males that also shed spores. The total number of sperm shed over the whole period was significantly higher $(\mathrm{p}<0.01)$ in frogs that shed spores $(12.2 \pm 6.5 \times$ $\left.10^{6}\right)$ than in those not shedding spores $\left(1.0 \pm 0.6 \times 10^{6}\right)$ (Table 2).

The testes of all 20 males were found to contain Myxobolus fallax cysts. Testes weight was greater in frogs releasing spores $(n=3,0.024 \pm 0.008 \mathrm{~g})$ than in those not releasing spores $(\mathrm{n}=6,0.013 \pm 0.003 \mathrm{~g})$. All the frogs releasing spores had a high intensity of infection by $M$. fallax. However, some frogs that did not produce spores also had a high intensity of infection, with testes weights up to $0.030 \mathrm{~g}$. There was no relationship between sperm numbers and infection levels of $M$. fallax in frogs not releasing spores (Table 2). There were no $M$. fallax cysts or spores in the kidneys.

\section{DISCUSSION}

The coupling of spermiation and the shedding of Myxobolus fallax spores from Litoria fallax testes was shown by: (1) the synchronous shedding of spores and sperm during both natural and hormonally induced spermiation; (2) no shedding of spores without the

Table 1. Litoria fallax. Body weight and length (snout-vent), number of oocytes and larvae, hatch success, occurrence of $M y x o-$ bolus fallax spores, intensity of $M$. fallax infection, and total testes weight of 6 pairs of $L$. fallax collected when naturally amplexing. $\mathrm{H}_{2} \mathrm{O} M$. fallax: presence or absence of $M$. fallax spores in fertilization media; Testes $M$. fallax: intensity of $M$. fallax infection in testes; NA: not applicable

\begin{tabular}{|c|c|c|c|c|c|c|c|c|c|}
\hline Pair & Sex & $\begin{array}{l}\text { Weight } \\
\text { (g) }\end{array}$ & $\begin{array}{c}\text { Length } \\
\text { (mm) }\end{array}$ & Oocytes & Larvae & $\%$ hatched & $\begin{array}{c}\mathrm{H}_{2} \mathrm{O} \\
\text { M. fallax }\end{array}$ & $\begin{array}{l}\text { Testes } \\
\text { M. fallax }\end{array}$ & $\begin{array}{c}\text { Testis weight } \\
(\mathrm{g})\end{array}$ \\
\hline \multirow[t]{2}{*}{1} & M & 0.9 & 24.9 & 283 & 281 & 99 & No & Low & 0.0075 \\
\hline & $\mathrm{F}$ & 1.09 & 27.4 & & & & & & \\
\hline \multirow[t]{2}{*}{2} & M & 27.7 & 0.89 & 261 & 47 & 18 & No & No & 0.0050 \\
\hline & $\mathrm{F}$ & 26.7 & 0.92 & & & & & & \\
\hline \multirow[t]{2}{*}{3} & $\mathrm{M}$ & 22.5 & 0.65 & 241 & 226 & 94 & No & Low & 0.0059 \\
\hline & F & 27.7 & 0.75 & & & & & & \\
\hline \multirow[t]{2}{*}{4} & $\mathrm{M}$ & 24.7 & 0.97 & 0 & 0 & NA & No & No & 0.0063 \\
\hline & $\mathrm{F}$ & 28.9 & 1.25 & & & & & & \\
\hline \multirow[t]{2}{*}{5} & $\mathrm{M}$ & 26.4 & 1.19 & 680 & 663 & 98 & Yes & High & 0.0250 \\
\hline & $\mathrm{F}$ & 30.1 & 1.33 & & & & & & \\
\hline \multirow[t]{2}{*}{6} & $\mathrm{M}$ & 23.6 & 1.02 & 450 & 330 & 73 & No & Low & 0.0057 \\
\hline & $\mathrm{F}$ & 26.6 & 1.07 & & & & & & \\
\hline
\end{tabular}


Table 2. Litoria fallax. Number of sperm and spores released into water from individual frogs in the human chorionic gonadotrophin (hCG) induction group and their intensity of infection with Myxobolus fallax. Sperm and spore counts at 3 and $6 \mathrm{~h}$ post-administration (PA) and summed counts. Spore and sperm numbers expressed as $\times 10^{6} .{ }^{*} p<0.01$

\begin{tabular}{|c|c|c|c|c|c|c|c|c|}
\hline \multirow[t]{2}{*}{ Frog no. } & \multicolumn{3}{|c|}{ - Sperm } & \multicolumn{3}{|c|}{ _-Spores } & \multirow{2}{*}{$\begin{array}{c}\text { Testes weight } \\
\text { (g) }\end{array}$} & \multirow{2}{*}{$\begin{array}{l}\text { Infection } \\
\text { intensity }\end{array}$} \\
\hline & $3 \mathrm{~h}$ PA & $6 \mathrm{~h} \mathrm{PA}$ & Total & $3 \mathrm{~h}$ PA & $6 \mathrm{~h} \mathrm{PA}$ & Total & & \\
\hline \multicolumn{9}{|c|}{ Releasing spores } \\
\hline 1 & 1.8 & 22.0 & 23.7 & 0.9 & 1.2 & 2.0 & 0.0083 & High \\
\hline 2 & 10.2 & 1.5 & 11.7 & 0.3 & 0.2 & 0.5 & 0.0344 & High \\
\hline 3 & 1.2 & 0.01 & 1.2 & 4.4 & 0.4 & 5.0 & 0.0286 & \\
\hline Mean $\pm \mathrm{SE}$ & $4.4 \pm 2.9$ & $7.8 \pm 7.1$ & $12.2 \pm 6.5^{*}$ & $1.9 \pm 1.3$ & $0.6 \pm 0.3$ & $2.5 \pm 1.3$ & $0.0238 \pm 0.0079$ & High \\
\hline \multicolumn{9}{|l|}{$\begin{array}{l}\text { Not releasing } \\
\text { spores }\end{array}$} \\
\hline 4 & 0.9 & 0 & 0.9 & 0 & 0 & 0 & 0.0296 & High \\
\hline 5 & 0 & 0 & 0 & 0 & 0 & 0 & 0.0075 & Low \\
\hline 6 & 4.2 & 0 & 4.2 & 0 & 0 & 0 & 0.0083 & High \\
\hline 7 & 0.3 & 0 & 0.3 & 0 & 0 & 0 & 0.0062 & Low \\
\hline 8 & 0.3 & 0 & 0.3 & 0 & 0 & 0 & 0.0115 & High \\
\hline 9 & 0.6 & 0 & 0.6 & 0 & 0 & 0 & 0.0116 & High \\
\hline 10 & 0.8 & 0 & 0.8 & 0 & 0 & 0 & 0.0180 & High \\
\hline Mean $\pm \mathrm{SE}$ & $1.0 \pm 0.6$ & 0 & $1.0 \pm 0.6$ & 0 & 0 & 0 & $0.0132 \pm 0.0031$ & \\
\hline Total $(\mathrm{n}=10)$ & $2.0 \pm 1.0$ & $2.4 \pm 2.2$ & $4.4 \pm 2.4$ & $0.7 \pm 0.4$ & $0.2 \pm 0.1$ & $0.8 \pm 0.5$ & $0.0164 \pm 0.0106$ & \\
\hline
\end{tabular}

shedding of sperm; (3) no controls shedding sperm or spores; and (4) the testes being the only source of spores. This coupling shows that $M$. fallax depends on endocrine-mediated changes in the testis associated with spermiation for the shedding of spores.

The infection of Litoria fallax by Myxobolus fallax is apparently benign. $M$. fallax infection does not affect body condition, sperm numbers, or the behavior of $L$. fallax. Males will vigorously call and amplex when their testes are enlarged up to 10 times the normal weight, and numerous testicular sperm are found in males with high intensities of infection (Browne et al. 2003). To maintain sperm production, normal numbers of spermatogenic cysts must be present in the testes of L. fallax, without the loss of spermatogenic tissue and degeneration of testes observed in other anurans infected with Myxobolus spp. (Johnston \& Bancroft 1918, Ewers 1973). In L. darlingtoni infected with M. chimbuensis, few sperm were noted and little meiotic activity was observed (Ewers 1973), and in L. hylae infected with $M$. hylae, the enlarged testes were degenerate (Johnston \& Bancroft 1918). The maintenance of normal testicular functions in infected $L$. fallax suggests: (1) compensatory mechanisms to enable structural changes in testes in order to support M. fallax cysts while maintaining spermatogenesis; (2) immune tolerance of $M$. fallax in the testes; and (3) nutritional support by L. fallax of M. fallax cysts.

The shedding of sperm is hormonally mediated and associated with hydration of the seminiferous tubules (Burgos \& Vitale-Cape 2005). The correspondence of the shedding of Litoria fallax sperm and Myxobolus fallax spores shows that the same mechanism sheds spores. Cone (1998) reported that Myxobolus spp. spores were released through stretching of the bulbus arteriosis and the rupturing of cysts. Similarly, hydration of the testes during spermiation ruptures M. fallax cysts and enables the passage of spores into the efferent ducts along with sperm. However, the efficacy of this mechanism must be reduced in anurans with testes damaged as a consequence of Myxobolus spp. infections less benign than those of M. fallax (Johnston \& Bancroft 1918, Ewers 1973). M. fallax was not found in the kidneys. Although the kidneys are intimately associated with the urogenital tract, Myxobolus spp. cysts in kidneys would not have a mechanism to couple spore release with spermiation.

Myxobolus fallax is confined to the testes of Litoria fallax. In other anurans, Myxobolus spp. infection is confined to the testes (M. bufonis, Upton et al. 1992; Myxobolus spp., Theodorides et al. 1981; M. chimbuensis, Ewers 1973; M. hylea, Johnston \& Bancroft 1918), but $M$. hylae also occurs in other organs associated with the urogenital tract, e.g. in the vasa efferentia, oviduct, kidney, and urinary bladder (Johnston \& Bancroft 1918). In anurans, only one Myxobolus sp. ( $M$. ranae) infects the skin, an organ not associated with the urogenital tract. However, as with the testes, the skin also offers direct access to the aquatic environment (Guyenot \& Naville 1922).

The stages of the full cycle of the transmission of Myxobolus fallax are not known. Nevertheless, the shedding of spores during the spawning of Litoria fallax deposits them into breeding ponds where further transmission must occur. A particular organ's infection by Myxobolus spp. is closely associated with its poten- 
tial as a site for spore dispersal and subsequent reinfection (Urawa \& Awakura 1994). The shedding of M. fallax spores during spawning could deposit spores where eggs, larvae, or adult $L$. fallax could be directly infected or could transmit $M$. fallax to an aquatic intermediate host. Infection of fish by actinospores released from an intermediate oligocheate host is a characteristic life stage of many Myxobolus spp. (Urawa \& Awakura 1994, El-Mansy \& Molnar 1997, Szekely et al. 2002, Blazer et al. 2003). The aquatic habitats of L. fallax are subject to periodic severe droughts. The shedding of $M$ fallax spores during reproduction would deposit spores, which are denser than water, on the bottom of ephemeral breeding ponds. M. fallax has spores that are tolerant of desiccation (Browne et al. 2003), and their deposition in the sediment of dry ponds would provide a survival mechanism until wetter conditions returned.

\section{CONCLUSION}

The shedding of the spores of Myxobolus fallax from the testes corresponds with spermiation during reproduction. This sexually mediated shedding of $M$. fallax spores results in spores being deposited in breeding ponds. The deposition of $M$. fallax spores into the aquatic environment at spawning could provide a cyclic mechanism for the efficient re-infection of susceptible populations of Litoria fallax. The advantages of spore deposition during reproduction could have resulted in the restriction of $M$. fallax infection to the testes. However, the mechanisms behind the intensity of infection of the testes by $M$. fallax - without apparent pathology and, particularly, any affect on reproduction of L. fallax - are unknown. Further studies are warranted to fully understand this host-parasite relationship.

\section{LITERATURE CITED}

Ali MA, Al-Rasheid KA, Sakran T, Abdel-Baki AA, AbdelGhaffar FA (2002) Some species of the genus Myxobolus (Myxozoa: Myxosporea) infecting freshwater fish of the River Nile, Egypt, and the impact on their hosts. Parasitol Res 88:9-15.

Bahri S, Andree KB, Hedrick RP (2003) Morphological and phylogenetic studies of marine Myxobolus spp. from mullet in Ichkeul Lake, Tunisia. J Eukaryot Microbiol 50: 463-470

Blazer VS, Waldrop TB, Schill WB, Densmore CL, Smith D (2003) Effects of water temperature and substrate type on spore production and release in eastern Tubifex tubifex worms infected with Myxobolus cerebralis. J Parasitol 89: $21-26$
Browne RK, Mahony M, Clulow J (2002) A comparison of sucrose, saline, and saline with egg-yolk diluents on the cryopreservation of cane toad (Bufo marinus) sperm. Cryobiology 44:251-257

Browne RK, Scheltinga DM, Pomering M, Mahony M (2003) Testicular myxosporidiasis in anurans, with a description of Myxobolus fallax n. sp. Syst Parasitol 52:97-110

Browne RK, Li H, Seratt J, Kouba A (2006) Progesterone improves the number and quality of hormone induced Fowler toad (Bufo fowleri) eggs. Reprod Biol Endocrinol $4: 3$

Burgos MH, Vitale-Calpe R (2005) The mechanism of spermiation in the toad. Am J Anat 120:227-251

Cone DK, Overstreet RM (1998) Species of Myxobolus (Myxozoa) from the bulbus arteriosus of centrarchid fishes in North America, with a description of two new species. J Parasitol 84:371-374

El-Mansy A, Molnar K (1997) Extrapiscine development of Myxobolus drjagini Akhmerov, 1954 (Myxosporea: Myxobolidae) in oligochaete alternative hosts. Acta Vet Hung 45:427-438

Ewers WH (1973) Myxobolus chimbuensis sp. n. (family Myxobolidae: Cnidosporidia; Protozoa) from the testes of the hylid frog Litoria darlingtoni from New Guinea. Sci New Guinea 1:16-20

Guyenot E, Naville A (1922) Su rune myxosporidie (Myxobolus ranae $\mathrm{n}$. sp.) et une microsporidie parasites de Rana temporaria. Rev Suisse Zool 29:413-425

Johnston TH, Bancroft MJ (1918) A parasite Myxobolus hylae $\mathrm{n}$. sp. of the reproductive organs of the golden swamp frog, Hyla aurea. J R Soc NSW 43:171-175

Kent ML, Khattra J, Hedrick RP, Devlin RH (2000) Tetracapsula renicola n. sp. (Myxozoa : Saccosporidae); the PKX myxozoan-the cause of proliferative kidney disease of salmonid fishes. J Parasitol 86:103-111

Landsberg J H, Lom J (1991) Taxonomy of the genera of the Myxobolus/Myxosoma group (Myxobolidaesporea), current listing of species and revision of syno-nyms. Syst Parasitol 18:165-186

Nieuwkoop PD, Faber J (1996) A systematical and chronological survey of the development from the fertilized egg until the end of metamorphosis. In: Nieuwkoop PD, Faber J (eds) Normal table of Xenopus laevis. Garland Publishing, New York

Pudney J (1995) Spermatogenesis in non-mammalian vertebrates. Microsc Res Tech 32:459-497.

Sprando RL, Russell LD (1998) Spermiogenesis in the bullfrog (Rana catesbeiana): a study of cytoplasmic events including cell volume changes and cytoplasmic elimination. J Morphol 198:303-319

Szekely C, Racz O, Molnar K, Eszterbauer E (2002) Development of Myxobolus macrocapsularis (Myxosporea: Myxobolidae) in an oligochaete alternate host, Tubifex tubifex. Dis Aquat Org 48:117-123

Theodorides J, Pujol P, Neyrand-De-Leffemebr F, Delso M (1981) New cases of testicular parasitism of amphibians by myxosporideans of the genus Myxobolus. Bull Soc Zool France 106:386

Upton SJ, Freed PS , Freed DA, McAllister CT, Goldberg SR (1992) Testicular myxosporidiasis in the flat-backed toad, Bufo maculatus (Amphibia: Bufonidae), from Cameroon, Africa. J Wildl Dis 28:326-329

Urawa S, Awakura T (1994) Protozoan diseases of freshwater fishes of Hokkaido. Sci Rep Hokkaido Fish Hatch 48: $47-58$ 